\title{
Investigation on different mulch materials and chemical control for controlling weeds in apple orchard in Turkey
}

\author{
Tamer Ustuner ${ }^{1}$ and Menderes Ustuner ${ }^{2 *}$ \\ ${ }^{1}$ Nigde University, Ulukisla Vocatioanal High School, Nigde, Turkey. \\ ${ }^{2}$ Cag University, Mersin, Turkey. \\ Accepted 15 August, 2011
}

\begin{abstract}
Five different applications of mulching, consisting of a cover of black plastic cover (polyethylene $=0.15$ $\mathrm{mm}$ thick), a sand stratum with a thickness of $2 \mathrm{~cm}$, a layer of sand with a thickness of $4 \mathrm{~cm}$, cardboard (1.5 $\mathrm{mm}$ thick), wheat stem $(5 \mathrm{~cm}$ thick) and glyphosate acid active substance herbicide (postemerging), respectively were used for weed control in apple orchard having different kinds of Scarlet spur, Grany smith and Red chif. 47 species of weeds belonging to 19 families were identified on the research field. Densities of weeds identified aforesaid according to application research is 0.081 , 19.256, 1.243, $0.209,26.625$ and $5.799 \mathrm{weeds} / \mathrm{m}^{2}$ respectively. Therefore, percent of effectiveness of aforementioned applied methods for control with weeds were determined as $99.86,68.82,97.98,99.66$, 56.89 and $90.61 \%$, respectively. While the method using a cover of black plastic (polyethylene) comes first with an effectiveness of $99.86 \%$, it was followed by cardboard method with $99.66 \%$, sand method with $\mathbf{9 7 . 9 8} \%$ and herbicide (touchdown = glyphosate acid) method with $\mathbf{9 0 . 6 1 \%}$.
\end{abstract}

Key words: Mulch method, weed, apple orchard.

\section{INTRODUCTION}

The cultivation of apples has a great importance in Turkey. Nigde occupies the first place for cultivation of apples with a farming area of 20.345 hectares, taking the second place with a crop capacity of 135.322 tones in Turkey (Anonymous, 2006). There are so many factors affecting the quality and crop capacity for fruits. One of these is weed. One of the methods applied to control weeds while making organic agriculture is mulching. Weeds are among important troubles for agricultural production worldwide. It is essential to fight against weeds in order to maintain the quality of crops. Particularly, usage of herbicides causes negative effects for environment and crops. Weed scientist have stated that there has been a requirement for new integral methods of control against weeds so that negative effects and inputs of herbicides could be decreased (Rifai et al., 2002). Researchers have started developing alternative methods for cultivation because of side effects of

${ }^{\star}$ Corresponding author. E-mail: mustuner@cag.edu.tr. Tel: +90 3246514800. residuals, especially pesticides, synthetic fertilizer and hormones on humans and environment. Weeds are one of the important factors that restrict the crop capacity in organic agriculture. Mulching method is divided into two groups: organic and synthetic material. Lifeless mulch is usually applied by covering rows with a material which does not transmit light. Some materials such as black nylon, straw, sawdust, rice stem, etc. are used for this purpose. However, mulch is used to control weeds. Also it is used to keep the root of any plant from high temperatures and soil moisture in good levels (Wade and McLaurin, 2009).

Usage of plastic mulch during the first two years of crops makes many contributions for crop capacity in plantations. The quality of crop depends mainly on what kind of mulch is used (Link, 1997). When different control methods against weeds are compared to fruit trees that were growing up, the mulching method that comprised of barks became the first among the suitable methods and application of herbicides took the second place. The third was the plots of land which were hoed. The mulching methods both increase crop capacity and quality, and decrease usage of herbicides (Kawecki et al., 1999; 
Szwedo and Maszczyk, 2000; Engel et al., 2001; Szewczuk and Gudarowska, 2006). It was stated that some materials such as pine leaves, scapes, bales of straw, turf, etc. could be used as mulching material, and some plastics in different colors and thicknesses could also be used practically. Thus, plastic mulches would increase the temperature of soil in a value of 3 to $5^{\circ} \mathrm{C}$, and for this reason, it would ensure better blossoming of roots and stimulate powerful growth. Additionally, plastic mulches keep the soil moisture (Smith et al., 2000); although usage of herbicides together with organic mulching applies more useful effects for weeds of multiyear when comparaed to the application of herbicides only (Rifai et al., 2002). The most important species encountered in average densities per apple area in Nigde region were determined as Agropyron repens (L.) P. Beauv., Alopecurus myosuroides Hudson, Bromus tectorum L. and Cynodon dactylon (L.) Pers. respectively.

While the $A$. repens (L.) P. Beauv among these species became in first range with a ratio of $84.6 \%$ among the most often encountered weeds, B. tectorum L. (72.2\%), A. myosuroides Hudson (54.9\%) and Dactylis glomerata L.( $49.2 \%)$ respectively (Ustuner and Akyol, 2007). The study carried out by Carter (2003) has revealed that the most important advantages of mulch method were its unselectiveness for taking under control of the weeds, features for keeping the soil moisture and effectiveness in long terms. Nonetheless, this study is aimed to determine the effects of each mulch methods and herbicide against weed species in the apple orchard.

\section{MATERIALS AND METHODS}

This study was carried out on an apple orchard belonging to the vocation school of Ulukisla located in Ulukisla district of Nigde between 2006 and 2008 in Turkey. Five different mulch applications and chemical control were applied. Consisting of a black plastic (polyethylene $=0.15 \mathrm{~mm}$ thick) cover (No. 1 plot of land), a sand stratum with a thickness of $2 \mathrm{~cm}$ (No. 2 plot), a layer of sand with a thickness of $4 \mathrm{~cm}$ (No. 3 plot), cardboard (1.5 mm thick) (No. 4 plot), wheat stem with a thickness of $5 \mathrm{~cm}$ (No. 5 plot) and herbicide glyphosate acid (No. 6 plot) respectively were used in the apple orchard which has Scarlet spur, Grany smith and Red chif (6 years) types. For control treatment (plot No. 7), any of these mulching and chemical methods were applied. The trial was set up according to a test pattern of coincidence blocks consisting of 7 blocks and 6 characters. 5 rows of apple trees were selected for each application; each row was with a lenght of $50 \mathrm{~m}$ and wideness of 1 $\mathrm{m}$, and the materials used on each row were applied to right and left hand sides of the plant with a width of $50 \mathrm{~cm}$. The postemergence herbicide with an effective substance of glyphosate acid was applied on testing plots in a ratio of $300 \mathrm{cc} /$ one-tenth of a hectare, while the weeds were in a period when they were found with 3 to 4 leaves. Hence, herbicide was sprayed with back-pump. Hoses of drip irrigation were placed under materials for polyethylene application and other applications. Also, manure application was carried out by means of drip irrigation method. It was observed during the aforesaid application that other irrigation methods have no possibility for application. Usage of subject application was maintained for 2 years by stocking soil on sides of both polyethylene and cardboards.
The apple horticulture soil is resonated (46\%), mildly alkaline ( $\mathrm{Ph}$ $=7.2$ ), salty in medium level $(0.65 \%)$, highly calcererous $(30 \%)$, and has an organic substance content in medium level (2.5\%) Nitrogen (N) manure was applied three times yearly, phosphorus (P) once yearly, potassium $(\mathrm{K})$ twice yearly and iron $(\mathrm{Fe})$ twice yearly per the age of subject tree. Continental climate prevails over Ulukisla province, and the averages of climatic data obtained from the meteorology station during the lenght of the trial period (2 years) are $55.5 \%$ of relative humidity, $12.3^{\circ} \mathrm{C}$ of temperature and 24.38 $\mathrm{mm}$ of precipitation in the 2006 and 2008 years. Unidentified plant species were identified by contributions and assistances of Plant Production Department, Agriculture Faculty of Selcuk University; Biology Department, Science and Literature Faculty of Nigde University (Davis, 1965, 1988). Density of weeds was calculated by using formula:

Density = B/n (Guncan, 2009),

Where $\mathrm{B}=$ total number of units selected and $\mathrm{n}=$ number of specimens selected.

Weeds with wide leaves were counted as complete plants, and only the stems of weeds with narrow leaves were evaluated by counting their stems; and results were inscribed on survey cards. Since apple trees are multi-year trees, the orchard are covered by weeds encountered both in winter and summer seasons (Anonymous, 1995). The first period of the survey was carried out on the months of May and June, and the second period was on August and September.

\section{Scale of density}

A) High density (average of more than 10 plants in $\mathrm{m}^{2}$ ).

B) Dense (average of 1 to 10 plants in $\mathrm{m}^{2}$ ).

C) Mid density (average of 0.1 to 1 plants in $\mathrm{m}^{2}$ ).

D) Low density (average of 0.01 to 0.1 plants in $\mathrm{m}^{2}$ ).

E) Scarce (average of less than 0.01 plants in $\mathrm{m}^{2}$ ).

\section{RESULTS AND DISCUSSION}

Totally, forty-seven species of weeds belonging to nineteen families were identified on the apple orchard on which the aforesaid study was carried out. Six of the identified species were monocotyledone and forty-one of them were dicotyledone. While one family and three species for the application of the black plastic (polyethylene) cover (No. 1 plot), Eighteen families and forty-four species were determined for the application of a sand stratum with a thickness of $2 \mathrm{~cm}$ (No. 2 plot), one family and three species were determined for the application of a layer of sand with a thickness of $4 \mathrm{~cm}$ (No. 3 plot), five families and ten species were determined for the application of cardboard (No. 4 plot), eighteen families and forty-three species were determined for the application of wheat stem with a thickness of $5 \mathrm{~cm}$ (No. 5 plot), and five families and fourteen species were determined for the application of post-emergence herbicide (No. 6 plot). However, nineteen families and forty-seven species determined for the control application (with no material, No. 7 plot) were found on the trial orchard. Therefore, the most effective methods for density of weeds in aforementioned 
Table 1. The analysis of effects of different mulch and herbicide applications on density of weeds per Duncan testing density.

\begin{tabular}{cccccccc}
\hline Application & $\mathbf{N}$ & \multicolumn{5}{c}{ Subset for alpha $=\mathbf{0 . 0 5}$} \\
\hline & & 1 & 2 & 3 & 4 & 5 & 6 \\
4 & 5 & $0.08120^{\mathrm{a}}$ & & & & & \\
3 & 5 & $0.20900^{\mathrm{a}}$ & $0.20900^{\mathrm{ab}}$ & & & & \\
6 & 5 & & $1.24400^{\mathrm{b}}$ & & & & \\
2 & 5 & & & $5.79900^{\mathrm{c}}$ & & & \\
5 & 5 & & & & $19.25600^{\mathrm{d}}$ & & \\
7 & 5 & & & & & $26.62000^{\mathrm{e}}$ & \\
Sig. & 5 & & & & & & $61.76760^{\mathrm{f}}$ \\
\end{tabular}

Means for groups in homogeneous subsets are displayed.

applications were respectively determined as follows: 0.081 weeds $/ \mathrm{m}^{2}$ on black plastic (polyethylene) cover application, 0.209 weeds $/ \mathrm{m}^{2}$ on cardboard application, 1.243 weeds $/ \mathrm{m}^{2}$ on application of a layer of sand with a thickness of $4 \mathrm{~cm}, 5.799$ weeds $/ \mathrm{m}^{2}$ on herbicide application, 19.256 weeds $/ \mathrm{m}^{2}$ on application of a sand stratum with a thickness of $2 \mathrm{~cm}, 26.625$ weeds $/ \mathrm{m}^{2}$ on application of wheat stem with a thickness of $5 \mathrm{~cm}$ and 61.762 weeds $/ \mathrm{m}^{2}$ in control plots (Table 1).

Some circumferential tears around trunks of apple trees and growth of weeds with narrow leaves especially due to directly penetrating sunlight were observed for applications of black polyethylene and cardboard. While the black cover polyethylene method (one of the most effective methods among mulch methods) that was applied to prevent growth of weeds on apple orchards became the first range with an effectiveness of $99.86 \%$, the cardboard method of mulch became the second with $99.66 \%$ and the sand method (4 cm of thickness) became the third with $97.98 \%$. Therefore, effects of other methods such as $68.82 \%$ for mulch (wheat stem laid down with a thickness of $5 \mathrm{~cm}$ ) were found to be low. Some of the researchers worldwide who have carried out studies on this subject have obtained similar results. For instance, it was stated that a mulch of black plastic, cardboard or sand prevented seeds of weed to germinate, increased the growth of roots and fertility of soil by keeping soil moisture (Salmins and Buszard, 1993; Dewey et al., 1997; Kraus, 1998; Smith et al., 2000; Bielinska and Wisniewski, 2001; Rifai et al., 2002; Wiebel, 2002; Roper, 2004; Varga et al., 2004; Wade and Mclaurin, 2009). The statistical density of weeds on No. 1 and 4 parcels which were characterized alphabetically as: a) was found to be the same, while the density on No. 4 and 3 parcels which were characterized alphabetically as (ab) was similar to each other per Duncan testing; therefore, the procedures that were applied to prevent growth of weeds on the aforesaid parcels were statistically found in different species and in important densities when compared to other methods. However,
No. 6 parcel is (c), No. 2 parcel is (d), No. 5 parcel is (e), and No. 7 parcel is (f), and methods applied to the aforementioned parcels were found to be different and unimportant to each other (Table 1). It was determined by the application of the black polyethylene method that $A$. repens (L.) P. Beauv., C. dactylon (L.) Pers and $D$. glomerata $\mathrm{L}$. were scarce encountered species (E) (Figure 1).

The weed species determined in mid-densities (C) on the application plot of sand mulch (2 cm thick) are Acroptilon repens (L.) D. C. st., Adonis flammea Jacq, $A$. repens (L.) P. Beauv., A. myosuroides Huds, A. retroflexus L., B. tectorum L., Carduus sp., C. solstitialis subsp. solstitialis, Chenopodium album L., Cirsium arvense (L.) Scop., C. arvensis L., C. dactylon (L.) Pers., S. viridis (L.) Pal. Beauv., Fumaria officinalis L., Papaver rhoeas L., Polygonum aviculare L., Lactuca serriola L., M. perforata Merat., Sonchus asper (L.) Hill., Capsella bursa-pastoris (L.) Med., Sinapis arvensis L., Salsola ruthenica Iljin., Ranunculus arvensis L. and Trifolium sp. (Table 2); while the weed species determined in lowdensity (D) on the application plot of sand mulch $(4 \mathrm{~cm}$ thick) are A. repens (L.) P. Beauv., B. tectorum L., $S$. arvensis L., C. album L., S. ruthenica Iljin. and Trifolium $\mathrm{sp}$. On the other hand, scarce encountered plant species (D) are A. repens (L.) D.C.st., A. repens (L.) P. Beauv., B. tectorum L., C. dactylon (L.) Pers, Xanthium strumarium L., $X$. spinosum L., Heliotropium europaeum L., S. arvensis L., C. album L., S. ruthenica Iljin and Malva neglecta Wallr. Scarce encountered plant species (D) on the plot on which cardboard mulch method was applied are A. repens (L.) D.C.st., Agropyron repens (L.) P. Beauv., Boraeva orientalis Jaub. and Spach., B. tectorum L., C. dactylon (L.) Pers., S. arvensis L., C. album L. and Trifolium sp. It was observed that $A$. flammea Jacq., Alhagi pseudalhagi (Bieb.) Desv., Capsella bursapastoris (L.) Med., C. draba ssp draba (L.) Desv., C. arvense (L.) Scop., C. dactylon (L.) Pers and L. serriola $\mathrm{L}$. Were found in high densities (B); while $A$. repens (L.) P. Beauv., A. myosuroides Huds. and B. tectorum $\mathrm{L}$. 


\section{The densities of weeds on application plots}

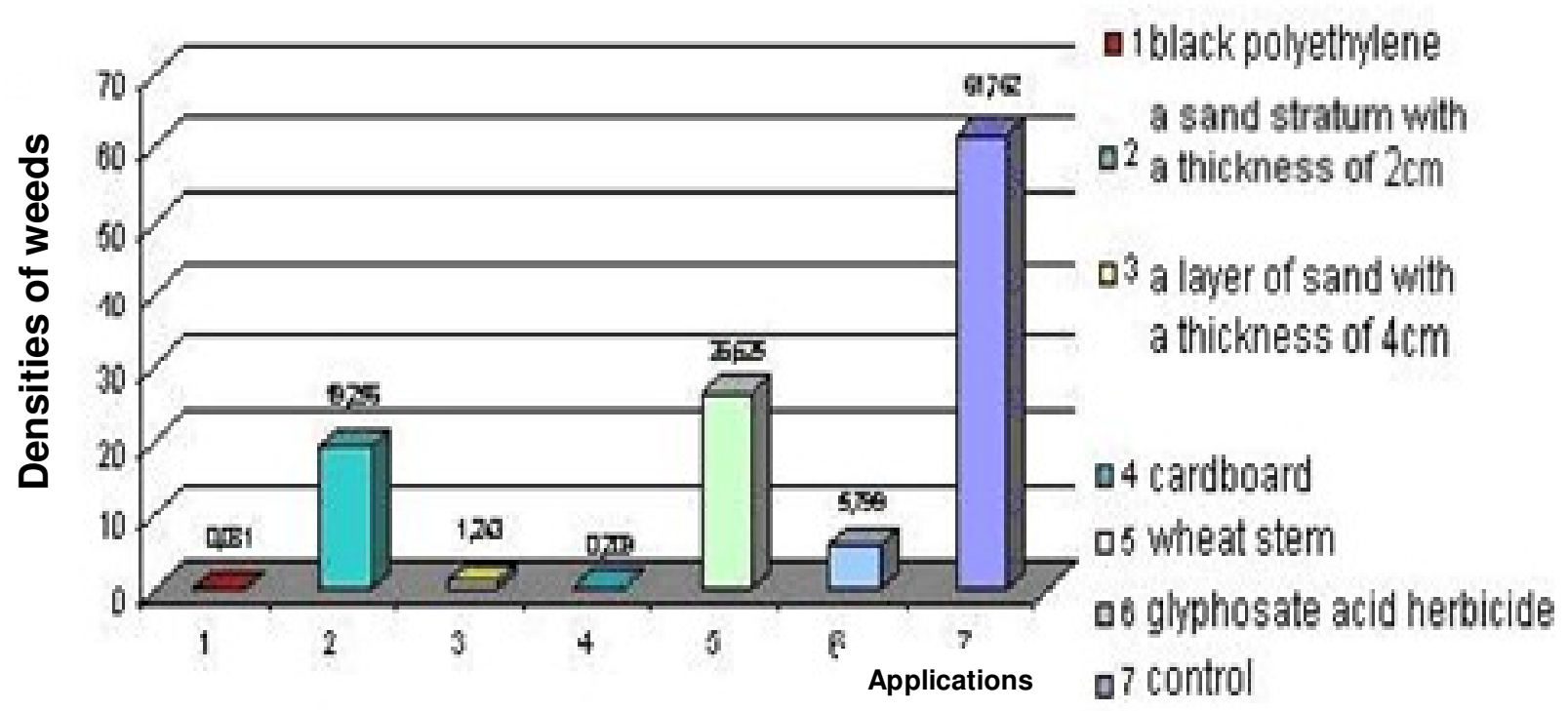

Figure 1. Densities of weeds on application plots.

were determined in mid densities $(C)$ on the plot in which post-emergence herbicide (glyphosate acid) was applied. Mulches, after chemical herbicide application are effective in controlling weeds (Rifai et al., 2002). Verdú and Mas (2007) explained that black geotextile and almond husk controlled the presence of weeds as well as or better than the applications of glyphosate at least during in Spain. The results of this study are similar to the results of these researchers.

The weed species determined in high-densities (B) on the application plot of wheat stem mulch $(5 \mathrm{~cm}$ thick) are A. repens (L.) P. Beauv., A. myosuroides Huds, $B$. tectorum L., C. dactylon (L.) Pers., D. glomerata L, S. viridis (L.) Pal. Beauv. D., A. repens (L.) D. C. st., C. arvensis $\mathrm{L}$. and $C$. galaticus Rost. Ex Choisy.; while, $A$. retroflexus L., C. solstitialis subsp. solstitialis, $C$. arvense (L.) Scop., L. serriola L. and M. perforata Merat. species were identified in mid densities $(C)$. The aforesaid weeds have similar characteristics when compared to the weeds observed in apple orchards located in Nigde region (Ustuner and Akyol, 2007). A mulch of wheat stem with a thickness of $5 \mathrm{~cm}$ was used for the application, but effectiveness ratio of this application resulted to $56.89 \%$ due to high blowing winds during vegetation period. Among studies done hroughout the world, Elmore and Tafoya (1993) found that a thickness of $10 \mathrm{~cm}$ was effective, while Bielinska and Wisniewski (2001) and Neilsen et al. (2003) found that a thickness between 2.5 and $15 \mathrm{~cm}$ was effective. The difference of results between these studies and ours depends on the regional ecological differences, the kind of materials used and the different thickness applications. Some troubles due to intensity of high blowing wind in Nigde region during summer vegetation period were encountered for application of this ethod. Other disadvantages of this method were as follows: these materials provided shelters for rodent animals, and became a place for hiding, laying eggs and spending winters inactively on rows of apple trees.

As a conclusion, while a cover of black plastic (polyethylene) method which is one of the most effective methods has become the first range with an effectiveness of $99.86 \%$, it was followed by cardboard method with $99.66 \%$, sand $(4 \mathrm{~cm})$ method with $97.98 \%$ and herbicide (glyphosate acid) method with $90.61 \%$.

\section{Conclusion}

In this study, the density ratios of weed species on control plot were determined as follows: $A$. repens (L.) P. Beauv., $B$. tectorum $\mathrm{L}$. and $D$. glomerata $\mathrm{L}$., were in very high densities (A), while $A$. flammea Jacq., $A$. repens (L.) D.C., A. myosuroides Huds., Amaranthus retroflexus L., Centaurea solstitialis subsp. solstitialis, Cardaria draba ssp draba (L.) Desv., Convolvulus arvensis L., Convolvulus galaticus Rost. Ex Choisy, C. dactylon (L.) Pers, Matricaria hamomilla L., Matricaria perforata Merat. and Setaria viridis (L.) Pal. Beauv. were in high densities (B). Effectiveness of these methods in percent for growth 
Table 2. Species of weeds identified in application orchard according to dispersion per trial plots.

\begin{tabular}{|c|c|c|c|c|c|c|c|}
\hline \multirow{2}{*}{ Species of weeds } & \multicolumn{7}{|c|}{ Different mulches and chemical methods applied and control plot } \\
\hline & 1 & 2 & 3 & 4 & 5 & 6 & 7 \\
\hline \multicolumn{8}{|l|}{ Monocotyledoneae } \\
\hline \multicolumn{8}{|l|}{ Family: Poaceae } \\
\hline Agropyron repens (L.) P.Beauv. A & 0.031 & 0.790 & 0.129 & 0.034 & 1.543 & 0.995 & 10.567 \\
\hline Alopecurus myosuroides Huds. & - & 0.397 & - & - & 1.002 & 0.088 & 1.346 \\
\hline Bromus tectorum $\mathrm{L}$. & - & 0.880 & 0.118 & 0.021 & 2.986 & 0.977 & 11.098 \\
\hline Cynodon dactylon (L.) Pers. & 0.023 & 0.656 & 0.124 & 0.012 & 3.008 & 2.012 & 3.986 \\
\hline Dactylis glomerata L. & 0.012 & 0.733 & 0.087 & 0.016 & 2.985 & 0.657 & 10.657 \\
\hline Setaria viridis (L.) Pal. Beauv.D & 0.015 & 0.420 & 0.062 & 0.013 & 2.087 & 0.148 & 2.568 \\
\hline \multicolumn{8}{|l|}{ Dicotyledoneae } \\
\hline \multicolumn{8}{|l|}{ Family: Amaranthaceae } \\
\hline Amaranthus retroflexus $\mathrm{L}$. & - & 0.325 & 0.074 & - & 0.985 & 0.001 & 1.234 \\
\hline \multicolumn{8}{|l|}{ Family: Aristolchiaceae } \\
\hline Aristolochia maurorum L. & - & 0.091 & - & - & 0.123 & - & 0.234 \\
\hline \multicolumn{8}{|l|}{ Family: Asteraceae } \\
\hline Acroptilon repens (L.) D.C.st. & - & 0.486 & 0.086 & 0.023 & 5.980 & 0.083 & 6.789 \\
\hline Carduus sp. & - & 0.423 & - & - & 0.023 & 0.026 & 0.070 \\
\hline Centaurea solstitialis subsp. solstitialis & - & 0.387 & - & - & 0.345 & - & 1.987 \\
\hline Cirsium arvense (L.) Scop. & - & 0.596 & 0.048 & 0.021 & 0.643 & 0.034 & 0.789 \\
\hline Lactuca serriola $\mathrm{L}$. & - & 0.428 & 0.032 & - & 0.879 & - & 0.945 \\
\hline Matricaria chamomilla L. & - & 0.357 & - & - & 0.862 & - & 1.456 \\
\hline Matricaria perforata Merat. & - & 0.243 & - & - & 0.056 & - & 1.003 \\
\hline Sonchus asper (L.) Hill & - & 0.345 & - & - & 0.001 & - & 0.564 \\
\hline Taraxacum officinale Çeb. & - & 0.568 & 0.059 & - & 0.321 & - & 0.756 \\
\hline Xanthium strumarium L. & - & 0.048 & 0.067 & - & 0.070 & 0.156 & 0.125 \\
\hline $\begin{array}{l}\text { Xanthium spinosum L. } \\
\text { Family: Boraginaceae }\end{array}$ & - & 0.036 & 0.021 & - & - & 0.146 & 0.102 \\
\hline $\begin{array}{l}\text { Heliotropium europaeum L. } \\
\text { Family: Brassicaceae }\end{array}$ & - & 0.230 & 0.042 & - & 0.877 & - & 0.980 \\
\hline Boraeva orientalis Jaub. and Spach. & - & 0.841 & - & 0.020 & 0.084 & - & 0.780 \\
\hline Cardaria draba ssp draba (L.) Desv. & - & 0.449 & - & 0.015 & 2.098 & - & 2.000 \\
\hline Capsella bursa-pastoris (L.) Med. & - & 0.287 & - & - & 0.09 & - & 0.987 \\
\hline $\begin{array}{l}\text { Sinapis arvensis } \mathrm{L} . \\
\text { Family: Caryophyllaceae }\end{array}$ & - & 0.796 & 0.043 & 0.013 & 0.007 & - & 0.543 \\
\hline $\begin{array}{l}\text { Stelleria media (L.) Vill. } \\
\text { Family: Chenopodiaceae }\end{array}$ & - & 0.528 & - & - & 0.004 & - & 0.133 \\
\hline Chenopodium album $\mathrm{L}$. & - & 0.469 & 0.012 & 0.011 & 0.006 & - & 0.259 \\
\hline Chenopodium vulvaria $\mathrm{L}$. & - & - & - & - & 0.001 & - & 0.123 \\
\hline Salsola ruthenica Iljin & - & 0.756 & 0.017 & - & 0.003 & 0.329 & 0.430 \\
\hline \multicolumn{8}{|l|}{ Family: Convolvulaceae } \\
\hline Convolvulus arvensis $\mathrm{L}$. & - & 0.368 & 0.024 & - & 3.930 & - & 4.970 \\
\hline $\begin{array}{l}\text { Convolvulus galaticus Rost. Ex Choisy. } \\
\text { Family: Cuscutaceae }\end{array}$ & - & 0.127 & - & - & 1.006 & - & 1.098 \\
\hline Cuscuta sp. & - & - & - & - & 0.002 & - & 0.560 \\
\hline \multicolumn{8}{|l|}{ Family: Euphorbiaceae } \\
\hline \multicolumn{7}{|l|}{ Family: Fabaceae } & 0.344 \\
\hline Alhagi pseudalhagi (Bieb.) Desv. & - & 0.148 & 0.038 & - & 0.001 & 0.147 & 0.080 \\
\hline Trifolium sp. & - & 0.642 & 0.042 & 0.010 & 0.001 & - & 0.030 \\
\hline Vicia sativa L. & - & 0.557 & - & - & - & - & 0.554 \\
\hline
\end{tabular}


Table 2. Contnd

\begin{tabular}{|c|c|c|c|c|c|c|c|}
\hline \multicolumn{8}{|l|}{ Family: Malvaceae } \\
\hline Malva neglecta Wallr. & - & 0.426 & 0.013 & - & 0.007 & - & 0.765 \\
\hline Malva sylvestris L. & - & 0.319 & - & - & 0.002 & - & 0.345 \\
\hline \multicolumn{8}{|l|}{ Family: Papaveraceae } \\
\hline Fumaria officinalis $\mathrm{L}$. & - & 0.635 & 0.032 & - & 0.001 & - & 0.247 \\
\hline Papaver rhoeas L. & - & 0.268 & - & - & 0.988 & - & 0.145 \\
\hline \multicolumn{8}{|l|}{ Family: Polygonaceae } \\
\hline Polygonum aviculare L. & - & 0.452 & - & - & 0.004 & - & 0.343 \\
\hline Rumex acetosella L. & - & 0.325 & 0.021 & - & 0.001 & - & 0.268 \\
\hline \multicolumn{8}{|l|}{ Family: Portulacaceae } \\
\hline Portulaca oleracea L. & - & 0.338 & - & - & - & - & 0.322 \\
\hline \multicolumn{8}{|l|}{ Family: Prımulaceae } \\
\hline Anagallis arvensis $\mathrm{L}$. & - & 0.137 & - & - & 0.006 & - & 0.345 \\
\hline \multicolumn{8}{|l|}{ Family: Ranunculaceae } \\
\hline Adonis flammea Jacq. & - & 0.728 & - & - & 0.008 & - & 1.003 \\
\hline Consolida regalis S.F.Gray & - & 0.546 & - & - & 0.002 & - & 0.543 \\
\hline Ranunculus arvensis L. & - & 0.334 & - & - & - & - & 0.445 \\
\hline \multicolumn{8}{|l|}{ Family: Zygophyhllaceae } \\
\hline Tribulus terrestris $\mathrm{L}$. & - & 0.076 & 0.011 & - & 0.001 & - & 0.566 \\
\hline Total & 0.081 & 19.256 & 1.243 & 0.209 & 26.625 & 5.799 & 61.762 \\
\hline
\end{tabular}

of weeds were determined respectively as follows: $99.86 \%$ for black polyethylene method, $99.66 \%$ for mulch (cardboard), $97.98 \%$ for mulch (a layer of sand with a thickness of $4 \mathrm{~cm}$ ), $90.61 \%$ for herbicide (glyphosate acid), $68.82 \%$ for mulch (a layer of sand with a thickness of $2 \mathrm{~cm}$ ) and $56.89 \%$ for mulch (wheat stem laid down with a thickness of $5 \mathrm{~cm}$ ). According to this study, black plastic cover (polyethylene), cardboard and sand applications are the most effective mulch methods and when compared to these methods, herbicide application is less effective. However, wheat stem (5 cm thick) was not found to be effective against weeds. The reason for this was found to be the bluster of winds in Nigde during the vegetation period.

\section{REFERENCES}

Anonymous (1995). Weeds in the fruit orchard, Technics instructions of agricultural protection, Ankara J. Crop horticul. science. (28): 53-58.

Anonymous (2006). Value, price, production, structure of agricultural. Data base of plantal production statistics. Statistics institution of Turkey publications. Printing of statistics, Ankara, Turkey, P.7.

Bielinska EJ, Wisniewski J (2001). Effect of orchard cultivation on physical and chemical properties of the soils derived from silty formations. Zeszyty problemowe postepow Nauk Rolniczych, 478: 79-87.

Carter K (2003). Weed management. Pome fruit IPM Specialist/Omafra, 519: 426-4322.

Davis PH (1965-1988). Flora of Turkey and The East aegean islands. University of Edinburg, England, 1-10: 300-312.

Dewey S, Drost D, Rupp L, Sagers L (1997). Landscape and garden weed control, 508: 45-48.

Elmore CL, Tafoya SM (1993). Water savings and weed control with mulches and plastics. Proceedings of the 45 th annual California weed conference. pp.147-154

Engel A, Kunz A, Blanke M (2001). Influences of compost and wood chips on Nutrient dynamics in soil, vegetative growth, fruit yield and fruit quality in apple in reproduction. Comm. Horticul., 43(6): 153-160.

Guncan A (2009). Weeds and control methods, Book publication of agriculture faculty, Page:79. Selcuk University, Agriculture faculty, Plant protection, Konya.

Kawecki Z, Kopytowski J, Tomaszewska Z (1999). The effect of two ways to maintain the soil on the growth and yield of 11 varieties of apple trees on rootstock M refined 26th Biul. Sci., 3: 49-59.

Kraus HT (1998). Effects of mulch on soil moisture and growth of desert willow. Hort Technology. 8: 464-626.

Link H (1997). Alternatives for herbicides in fruit growing. Proc. int. seminar "Ecological aspect of nutrition and alternatives for herbicides in horticulture",Warsaw, pp. 45-46.

Neilsen GH, Hogue EJ, Forge T, Neilsen D (2003). Mulches and biosolids affect vigor, yield and leaf nutrition of fertigated high density apple. HortScience, 38(1): 41-45.

Rifai MN, Astatkie T, Lacko-Bartosova M, Gadus J (2002). Effect of two different thermal units and three types of mulch on weeds in apple orchards. J. Environ. Eng. SCI., 1(5): 331-338.

Roper TR (2004). Orchard flor management for fruit trees. Collage of agricultural and life sciences, University of Wisconsin Madison and university of Wisconsin-Extension publication, 608: 262-8067.

Salmins S, Buszard D (1993). Weed control methods and tree growth In apple orchards: Part 2. Ecological agriculture projects, McGill University (Macdonald Campus) Ste-Anne-de-Bellevue, QC, H9X 3V9 Canada, 25(4): 65

Smith R, Lanini WT, Gaskell M, Mitchell J, Koike ST (2000). Weed management for organic crops. Vegetable research and information center. Organic vegetable production in California series. California. P.7250.

Szwedo J, Maszczyk M (2000). Effects of straw-mulching of tree rows on some soil characteristics, mineral nutrient uptake and cropping of sour cherry trees. J. Fruit Ornam. Plant Res., 8(3-4): 147-153.

Szewczuk A, Gudarowska E (2006). Effects of mulching in a nectarine orchard in sustainable fruit production. Department of horticulture,

University of agriculture in Wrocław Rozbrat, 7:50-334. Wrocław,

Poland J. fruit Ornamental plant res., 14: 217-223. 
Ustuner T, Akyol E (2007). Determination of the density and species weeds that cause problem in the apple orchards in Nigde province. J. Turkish weed sci., 10: 22-34.

Varga C, Bubán T, Piskolczi M (2004). Effect of organic mulching on the quantity of microorganisms in soil of apple plantation, Journal of fruit and ornamental plant research. College of Nyíregyháza, Hungary Department of land and environmental management, Hungary, Fruit production research and advisory Kht, Újfehértó, Hungary, 12: 49-51

Verdú AM, Mas MT(2007). Mulching as an alternative technique for weed management in mandarin orchard tree rows. Agron. Sustain. Dev., 27: 367-375.
Wade G, McLaurin W (2009). Composting orchards and mulching. Extension horticulturists Robert J. Black, Edward F. Gilman, Gary W. Knox and Kathleen C. Ruppert College of Agriculture \& Life Sciences. Depart. Horticul. Sci., 11: 133-142.

Wiebel F (2002). Soil management and in-row weed control in organic apple production, Compact fruit tree, 35: 118-121. 